\title{
Severity of gummy stem blight on melon in relation to cultivars, use of fungicides and growing season
}

\author{
Mateus S Dalcin; Paulo H Tschoeke; Raimundo WS Aguiar; Rodrigo R Fidelis; Julcemar Didonet; Gil R \\ Santos
}

Universidade Federal do Tocantins (UFT),Gurupi-TO, Brasil; mateussuntidalcin@hotmail.com; pht@uft.edu.br; rwsa@uft.edu.br; fidelisrr@ uft.edu.br; jdidonet@uft.edu.br; gilrsan@uft.edu.br (autor para correspondência)

\begin{abstract}
The authors aimed to evaluate the resistance to gummy stem blight and the agronomic traits of the melon crop in the Southern Region of the State of Tocantins, Brazil, in two growing seasons, submitted or not to treatment with fungicides. Two experiments were carried out: dry season (experiment I), and rainy season (experiment II), respectively, comprising the periods from July to October 2013 and from March to May 2014. Six melon cultivars were used in each season. In the dry season: Eldorado 300, Hibrix, Dourado Amarelo, Louro, Gaúcho Redondo and Canarian; and in the rainy season: Eldorado 300, Hibrix, HF-4439, Louro, Gaúcho Redondo and Canarian. Treatments consisted of each cultivar and split plot with (WA) or without fungicides application (NA). All cultivars were susceptible to disease, considering that Gaúcho Redondo was the least susceptible in the dry season. The fungicide application decreased disease severity in the dry season, however the productivity of the crop in treatments without fungicide application were not compromised, due to the late onset of the disease, and ranged from $19.2 \mathrm{t}$ /ha for Eldorado 300 up to $41.9 \mathrm{t} /$ ha for Canarian. The total soluble solids showed average values of $12^{\circ}$ Brix, except for cultivar Gaúcho Redondo, which showed Brix value lower than commercial standards. During the rainy season, fungicide application did not protect the plants, which did not complete the cycle, resulting in the absence of marketable fruit production. The climatic characteristics observed in the rainy season, with high humidity, leaf wetness and high temperatures are favorable for the development of gummy stem blight in melon plants. Thus, in Tocantins, the dry season is characterized as the best time of year for cultivation, between April and September.
\end{abstract}

Keywords: Cucumis melo, Stagonosporopsis cucurbitacearum, chemical control.

\section{RESUMO}

Severidade do crestamento gomoso do meloeiro em função de cultivares, uso de fungicidas e época de cultivo

No presente trabalho teve-se por objetivo avaliar a resistência ao crestamento gomoso do caule e as características agronômicas de cultivares de melão na região sul do estado do Tocantins, cultivados em duas estações climáticas e submetidas ou não à aplicação de fungicidas. Foram conduzidos dois experimentos: Estação seca (Experimento I) e Estação chuvosa (Experimento II), compreendendo os períodos de julho a outubro de 2013 e março a maio de 2014, respectivamente. Foram utilizadas seis cultivares de melão em cada época. No período de seca as cultivares utilizadas foram: Eldorado 300, Hibrix, Dourado Amarelo, Louro, Gaúcho Redondo e Canarian; época das chuvas: Eldorado 300, Hibrix, HF-4439, Louro, Gaúcho Redondo e Canarian. Os tratamentos consistiram de cada cultivar e a parcela subdividida em com (WA) e sem a aplicação de fungicidas (NA). Todas as cultivares foram suscetíveis à doença, sendo a Gaúcho Redondo a menos suscetível apenas na estação seca do ano. A aplicação de fungicidas diminuiu a severidade da doença na época seca, entretanto, a produtividade dos tratamentos sem aplicação não foi comprometida, devido ao aparecimento tardio da doença,variando de 19,2 t/ha para a Eldorado 300 até 41,9 t/ha para a Canarian. Os teores de sólidos solúveis totais apresentaram valores médios de $12^{\circ}$ Brix, com exceção da cultivar Gaúcho Redondo, que apresentou valor abaixo do padrão comercial. No período chuvoso, a aplicação de fungicidas não protegeu as plantas, que não completaram o ciclo, resultando na ausência de produção de frutos comerciais. As características climáticas verificadas na estação chuvosa, com alta umidade, molhamento foliar e elevadas temperaturas são favoráveis ao desenvolvimento do crestamento gomoso em plantas de melão. Desta forma, no Tocantins, a estação seca se caracteriza como a melhor época do ano para o cultivo, compreendida entre os meses de abril e setembro.

Palavras-chave: Cucumis melo, Stagonosporopsis cucurbitacearum, controle químico.

Received on December 2, 2016; accepted on August 8, 2017

$\mathrm{M}$ elon (Cucumis melo) is an oleraceae of great acceptance in the world market of fresh fruits, including Brazil (Vargas et al., 2008).
It is grown mainly in tropical countries, due to the climate characteristics (temperature, relative humidity and luminosity) which contribute positively to growing, development, and productive performance of the plants (Pereira Filho et al., 2014). Melon production in Brazil is around 570.000 ton, and the 
main commercial planting area is in the Northeastern semiarid, in the States of Rio Grande do Norte and Ceará (FAO, 2013).

Recently, in the State of Tocantins, melon has been grown in areas of watermelon production and showed good development and high productivity (Santos et al., 2011). However, high temperatures and the crop irrigation management favor disease occurrence (Queiroga et al., 2007). Thus, melon producers have been facing difficulties in controlling diseases, mainly the gummy stem blight, which has been causing losses in these growing areas.

Gummy stem blight or stem canker, caused by fungus Didymella bryoniae is one of the main diseases in melon worldwide. It causes damping-off, foliar lesions and stem and stalk cankers, which compromise the plant development, reducing productivity and quality of the fruits (Santos \& Café Filho, 2005). Recently, Aveskamp et al. (2010) proposed a new nomenclature for $D$. bryoniae, which was defined as Stagonosporopsis cucurbitacearum and anamorph in Phoma cucurbitacearum (Brewer et al., 2015).

The fungus survives in the absence of the host on and/or below the soil, in the cultural remnants of cucurbitaceae, weeds or in seeds. The pathogen is very resistant to sun and other hard weather conditions, remaining viable for several years in the soil (one to three years) and in cultural remnants. Diseased fruits generally show infected seeds, which are the main means of dissemination and survival of the fungus (Santos et al., 2005a).

So far, few studies, in the region, on the disease management can be found, thus the producers are prevented from expanding the growing areas due to the lack of technology developed in the region, and also because damage is increasing each year.

This study aimed to evaluate the resistance to gummy stem blight and agronomic traits of melon cultivars in the Southern Region of the State of Tocantins, in two different growing seasons (dry and rainy), submitted or not to fungicide treatment.

\section{MATERIAL AND METHODS}

Two trials were carried out in different seasons: dry season (Experiment I) and rainy season (Experiment II), from July to October 2013 and from March to May 2014, respectively, in Fitossanity department of Universidade Federal do

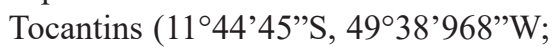
altitude $278 \mathrm{~m}$ ), municipality of Gurupi, State of Tocantins, Brazil. The area is inserted in the Bioma Cerrado, with a history of melon planting and natural infestation of gummy stem blight. The soil is classified as Typic Hapludox (Santos et al., 2013) with medium texture.

According to Köppen, the climate of the region is Aw, tropical, hot and humid, with rainy season in the summer and dry season in the winter. The annual average temperature is around $26^{\circ} \mathrm{C}$, annual average temperature amplitude very small, with monthly average minimum temperature of $20^{\circ} \mathrm{C}$ and monthly average maximum temperature of $33^{\circ} \mathrm{C}$. The average annual rainfall is $1,632 \mathrm{~mm}$, registering from October to March the highest rainfall indices and, from April to September, the lowest indices (Hargreaves \& Samani, 1985).

Soil preparation was carried out with two heavy harrowings and one leveling harrowing, whereas, to build the seedbeds, the authors used a rotary tilling $(0.70 \mathrm{~m}$ width at the upper base, $0.90 \mathrm{~m}$ width at the bottom base and 0.30 $\mathrm{m}$ height). The seedbeds were protected using double-sided plastic canvas (black/white) with 150 micrometers thickness, exposing the white face. Base fertilization was carried out using $1000 \mathrm{~kg} / \mathrm{ha}$ of $05-25-15$ (NPK). The top dressing fertilization was carried out using $262 \mathrm{~kg} / \mathrm{ha}$ of potassium chloride and $454 \mathrm{~kg} / \mathrm{ha}$ of urea, split in four applications. The authors used dripping irrigation system (3.6 L/hour) aiming to reach the field capacity and fixed irrigation shifts. Melon seedlings were produced in $300 \mathrm{~mL}$ disposable cups using commercial substrate. At 10 days after sowing, the authors carried out transplanting to the seedbeds, with spacing of $0.5 \mathrm{~m}$ between pits, maintaining 10 plants per subplot.
The experimental design was randomized blocks, the treatments were allocated in split plots, with four replicates. Six melon cultivars were used in each growing season. During the dry season: Eldorado 300, Hibrix, Dourado Amarelo, Louro, Gaúcho Redondo and Canarian; and during the rainy season: Eldorado 300, Hibrix, HF-4439, Louro, Gaúcho Redondo and Canarian. The treatments consisted of each cultivar and each split plot: with application (WA) and without application (NA) of any kind of product.

In the plots treated with fungicides, the authors used thiophanate methyl $20 \%$ $\mathrm{m} / \mathrm{m}$ i.a $(0.7 \mathrm{~g} / \mathrm{L})+$ chlorothalonil $50 \%$ $\mathrm{m} / \mathrm{m}$ i.a (1.7 g/L) and diphenoconazole $25 \% \mathrm{~m} / \mathrm{v}$ i.a. $(0.3 \mathrm{~mL} / \mathrm{L})$. Eight applications were carried out, being 7 of thiophanate + chlorothalonil. On the sixth application, diphenoconazole was used. In order to control pest insects, the authors used insecticides deltamethrin $2.5 \% \mathrm{~m} / \mathrm{v}$ i.a. $(1.0 \mathrm{~mL} / \mathrm{L})$ and imidacloprid $70 \% \mathrm{~m} / \mathrm{m}$ i.a. $(0.3$ $\mathrm{g} / \mathrm{L})$ in all applications, on the same days and plots of the fungicides. The first application was carried out after seedling emergence, another at 15 days after emergence and weekly after flowering totaling eight. The application of the products were carried out with the aid of a costal spray with capacity for 20 L, equipped with nozzles with spray tips full cone type. The quantity of syrup applied followed the manufacturer's instructions.

The severity of the disease in relation to time was determined every seven days, using a scale described by Santos et al. (2005b) and Sousa et al. (2014), where: $0=$ healthy plants; $1=$ plants with less than $1 \%$ of damaged leaf area; $3=$ plants between 1 and $5 \%$ of damaged leaf area; $5=$ plants between 6 and 25\% damaged leaf area; $7=$ pants between 26 and $50 \%$ of damaged leaf area; $9=$ plants showing more than $50 \%$ of damaged leaf area. Then, the grades attributed to disease in leaves were converted to percentages of diseased leaf area by using the midpoint of each grade, according to the number of evaluations of each trial, according to the onset of the disease. At the end of the evaluation, the data on severity were converted for 
Area Under Disease Progress Curve (AUDPC), according to the method described by Shaner \& Finney (1977).

Fruits were harvested and weighed and, then, total soluble solid content (TSS) was determined. Productivity was expressed in $\mathrm{t} / \mathrm{ha}$ and TSS in ${ }^{\circ}$ Brix. Collected data were submitted to the analysis of variance (ANOVA) and Tukey test at $5 \%$ probability was applied to compare the averages.

\section{RESULTS AND DISCUSSION}

\section{Experiment in the dry season}

All the cultivars submitted to fungicide application treatment (WA) showed lower Area Under Disease Progress Curve (AUDPC), differing statistically from the treatment without application (NA), except for Gaúcho Redondo, which did not show any statistical difference between the treatments with or without fungicides (Figure 1).

In treatment without fungicide, the cultivar Eldorado 300 showed the highest AUDPC value (227.5) differing statistically from the cultivars Hibrix (169.75) and Gaúcho Redondo (101.5); considering that this last one showed the highest resistance to gummy stem blight, both using fungicide treatment and using treatment without fungicide. For Keinath $(2000,2001,2014)$, due to a higher susceptibility of watermelon and melon to foliar blight, regular use of fungicides is recommended in environments conducive to disease.

The climatic variables recorded in the period in which the trial was carried out were total rainfall of 12.6 $\mathrm{mm}$, temperatures ranging from 15.5 to $38^{\circ} \mathrm{C}$ and relative humidity from 46.6 to $67.2 \%$. sixty six days after planting, when the first rains occurred, the disease severity increased sharply (Figure 2).

Considering the evolution of disease severity in the treatments over time, the authors could observe that in treatments without fungicide (Figure 2A), the disease began from 52 after planting (DAP), increasing after 59 DAP. The rainfall from $65 \mathrm{DAP}$, the increase of

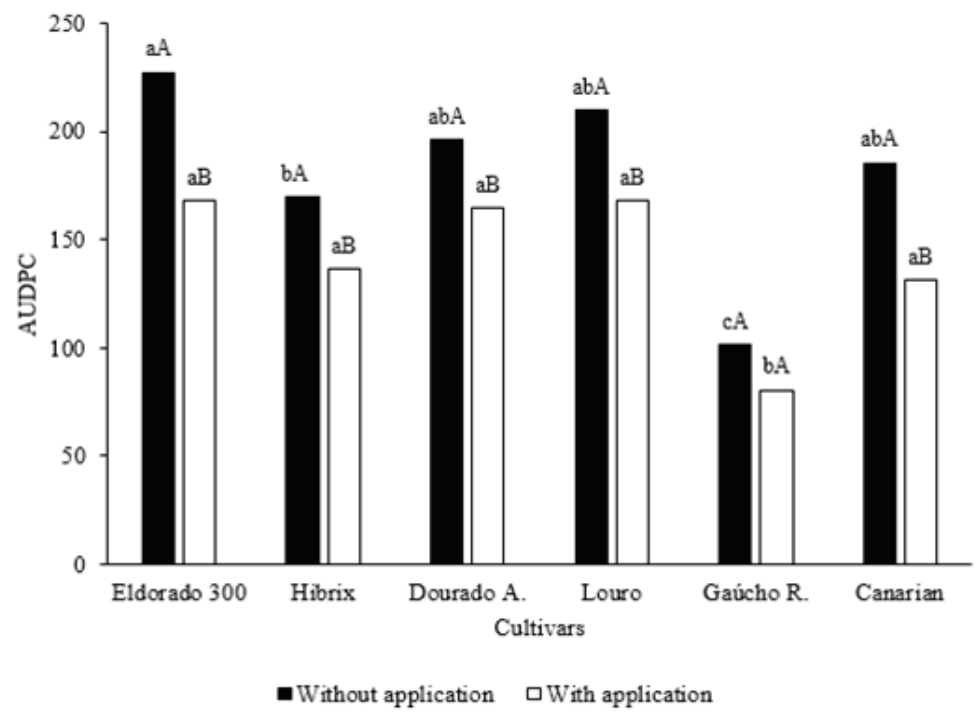

Figure 1. Area Under Disease Progress Curve (AUDPC) in melon cultivars with and without fungicide application in dry season. Averages followed by same lowercase letter among cultivars using the same treatments and uppercase letter among cultivars using different treatments do not differ significantly, from each other, by Tukey test, at 5\% probability. Gurupi, UFT, 2015.
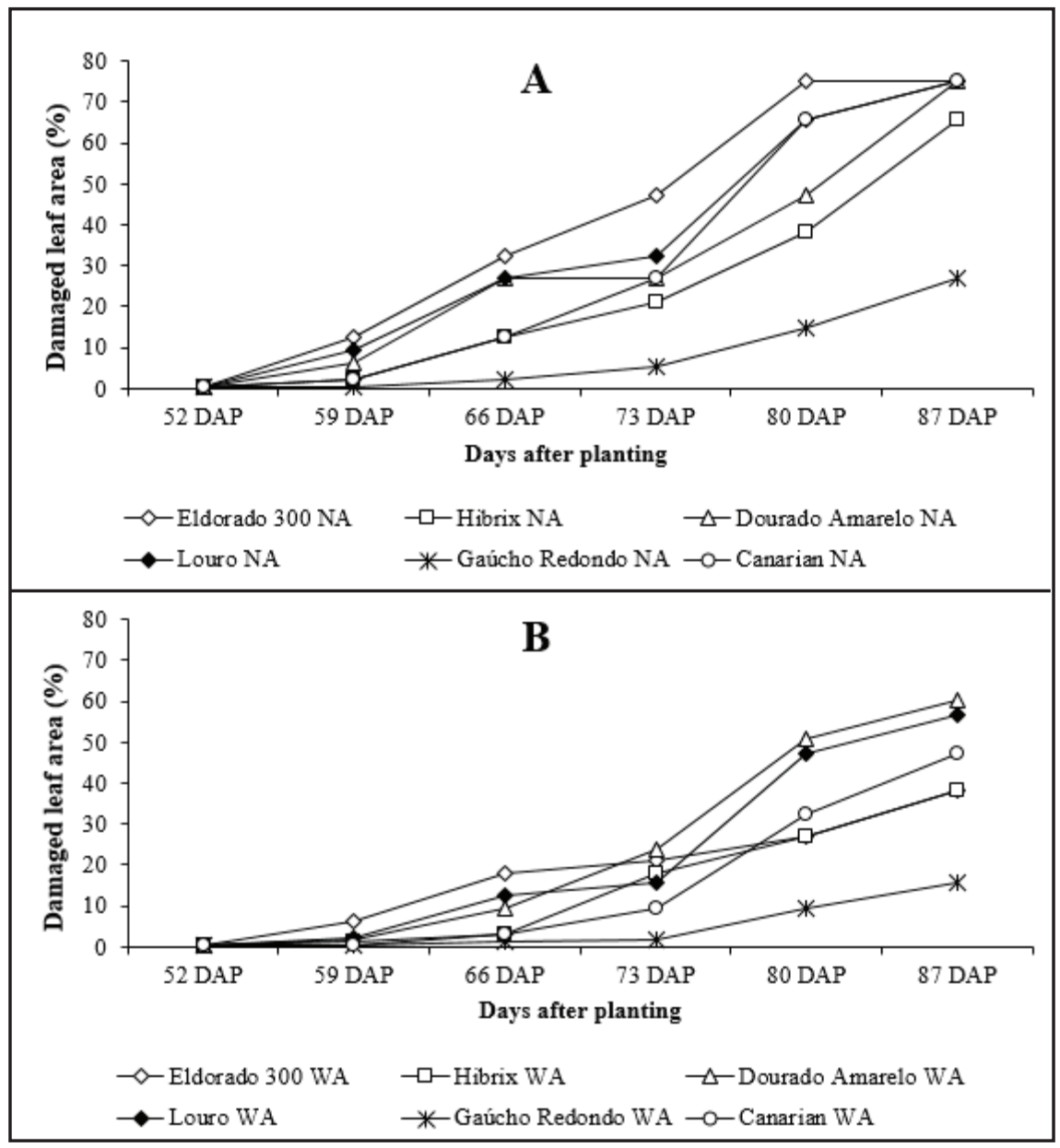

Figure 2. Temporal progress of gummy stem blight (\% damaged leaf area) in melon cultivars without application (NA) (A) and with application of fungicides(WA)(B), dry season. Gurupi, UFT, 2015. 
relative humidity and high temperature contributed to the onset of the disease and to the increase of the damaged leaf area. Santos et al. (2011) state that temperatures from 20 to $30^{\circ} \mathrm{C}$, with an optimum temperature around $25^{\circ} \mathrm{C}$ and relative humidity around 95\% are favorable for infection, caused by S. cucurbitacearum in the host. For cultivar Eldorado 300, the disease presented a more pronounced evolution, when compared to other cultivars, showing $0.5 \%$ of damaged leaf area at 52 DAP, $12.4 \%$ at 59 DAP, $32.4 \%$ at 66 DAP, $47.3 \%$ at 73 DAP, reaching a maximum of $75 \%$ of diseased leaf area after 80 DAP. Cultivar Gaúcho Redondo showed different behavior from Eldorado 300, maintaining low levels of disease severity, reaching the end of the cycle with only $26.8 \%$ of the affected leaf area (ALA).

The other cultivars maintained a median evolution of disease severity, among values showed in Eldorado 300 and cv. Gaúcho Redondo, however, they showed equal values at the end of the cycle in relation to percentage of damaged leaf area (about 75\%). Cultivar Hibrix did not show the same evolution when compared to the others, presenting a final damaged leaf area of $65.8 \%$.

Melon cultivars, evaluated by Keinath (2014) in the United States, reached maximum disease severity showing $99.8 \%$ of damaged leaf area, proving that this is a difficult disease to be controlled in all continents, due to the lack of resistance resources. According to the author, this disease is found in six continents in, at least, 12 genera and 23 species of cucurbitaceae (Keinath, 2011).

Besides resistance to diseases, the choice of cultivar should consider the commercialization, productivity, shelf life, resistance to pests and diseases, among other aspects (Freitas et al., 2007). The use of cultivars adapted to production systems and environmental conditions of the growing region and appropriate management of the crop are important factors in order to maximize yield (Silva et al., 2009).

Fungicide application slowed evolution and decreased disease severity (Figure 2B). In relation to cultivar
Eldorado 300, fungicide treatment provided reduction of almost $50 \%$ of final disease severity, from $75 \%$ of affected leaf area (ALA) in treatment without fungicide to $38 \%$ when defensives were used. Cultivar Gaúcho Redondo still showed the lowest severity levels, reaching the end of the cycle presenting $15 \%$ of ALA. In this case, cultivar Dourado Amarelo showed the lowest response in relation to fungicide use, keeping high ALA at the end of cultivation, about $60 \%$. When evaluating the resistance of fungus $D$. bryoniae to several fungicides, Santos et al. (2006) state that considering the high resistance of the pathogen to benzimidazoles, mainly to thiophanate methyl, it is important that the producer use in preventive applications other contact products, also registered for the crop, such as mancozeb, chlorothalonil and copper oxychloride. These fungicides present multi-sites of cellular and

Table 1. Average productivity (t/ha) and total soluble solid contents (TSS) $\left({ }^{\circ}\right.$ Brix) in melon cultivars without (NA) and with (WA) application of fungicides, dry season. Gurupi, UFT, 2015 .

\begin{tabular}{lccccc}
\hline \multirow{2}{*}{ Cultivar } & \multicolumn{2}{c}{ Productivity (t/ha) } & & \multicolumn{2}{c}{ TSS ('Brix) } \\
\cline { 2 - 3 } \cline { 5 - 6 } & NA & WA & & NA & WA \\
\hline Eldorado 300 & $19.7 \mathrm{bA}$ & $19.2 \mathrm{bA}$ & & $12.8 \mathrm{aA}$ & $12.5 \mathrm{aA}$ \\
Hibrix & $30.4 \mathrm{abA}$ & $27.6 \mathrm{abA}$ & & $12.9 \mathrm{aA}$ & $12.7 \mathrm{aA}$ \\
Dourado Amarelo & $31.5 \mathrm{abA}$ & $30.4 \mathrm{abA}$ & & $11.5 \mathrm{aA}$ & $12 \mathrm{aA}$ \\
Louro & $39.6 \mathrm{abA}$ & $31.5 \mathrm{abA}$ & & $12.5 \mathrm{aA}$ & $12 \mathrm{aA}$ \\
Gaúcho R. & $28.6 \mathrm{abA}$ & $32.1 \mathrm{abA}$ & & $8 \mathrm{bA}$ & $7.1 \mathrm{bA}$ \\
Canarian & $41.9 \mathrm{aA}$ & $41.3 \mathrm{aA}$ & & $11.5 \mathrm{aA}$ & $12.2 \mathrm{aA}$ \\
\hline
\end{tabular}

Averages followed by the same lowercase letter in the column and uppercase letter on line do not differ statistically by the Tukey test at $5 \%$ probability.

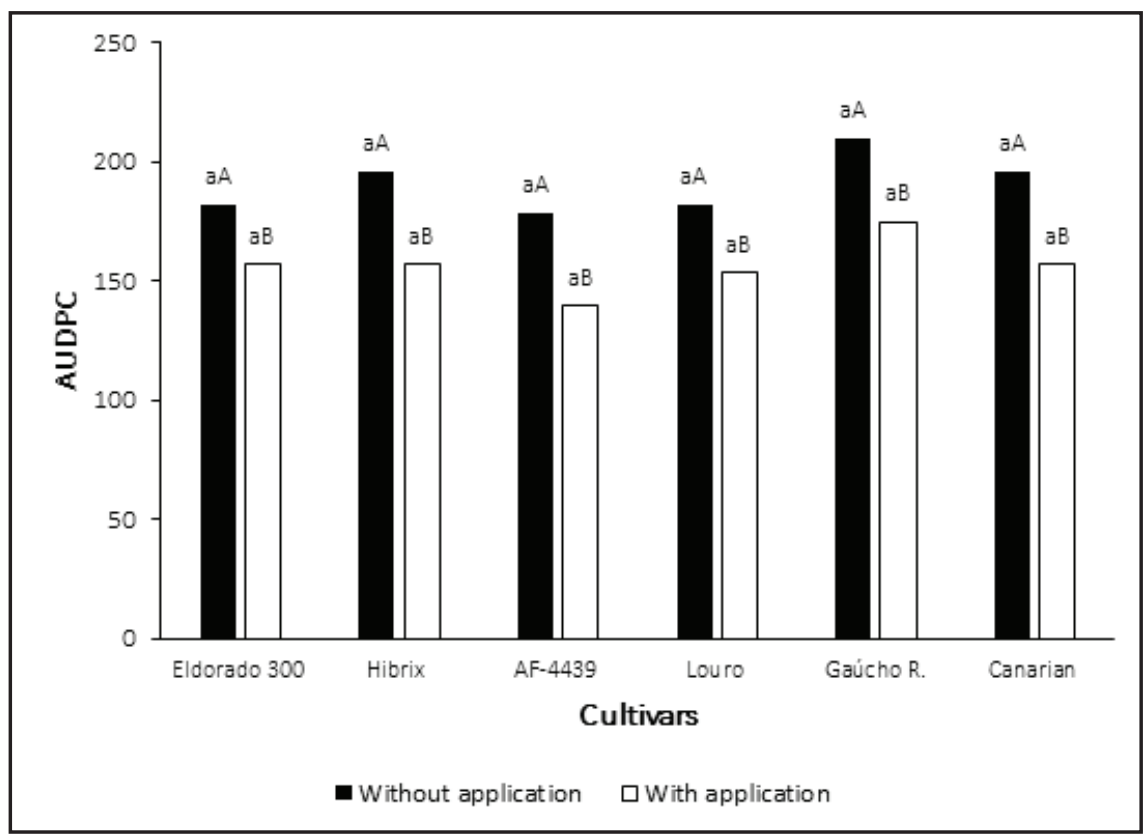

Figure 3. Area Under Disease Progress Curve (AUDPC) in melon cultivars with and without fungicide application in rainy season. Averages followed by same lowercase letter among cultivars using the same treatments and uppercase letter among cultivars using different treatments do not differ significantly, from each other, by Tukey test, at $5 \%$ probability. Gurupi, UFT, 2015. 
metabolic action and, therefore, they are safer against the emergence of resistant races, as well as the diphenoconazole used in this trial.

In relation to productivity, the authors verified that only cultivars Canarian and Eldorado 300 differed statistically among each other, considering that the first cultivar produced 41.9 and $41.3 \mathrm{t} /$ ha in treatment without fungicide and fungicide treatment, whereas Eldorado 300 produced 19.7 and $19.2 \mathrm{t} / \mathrm{ha}$, respectively (Table 1).

Comparing average productivities obtained by Reis et al. (2013) in the municipality of Porto Nacional-TO, which were around $25 \mathrm{t} / \mathrm{ha}$, which evaluated cultivars in Gurupi showed superiority, with exception of Eldorado 300 which produced less with average of $19.7 \mathrm{t} / \mathrm{ha}$ and $19.2 \mathrm{t} / \mathrm{ha}$ in treatment without fungicide and fungicide treatment, respectively. Freitas et al.

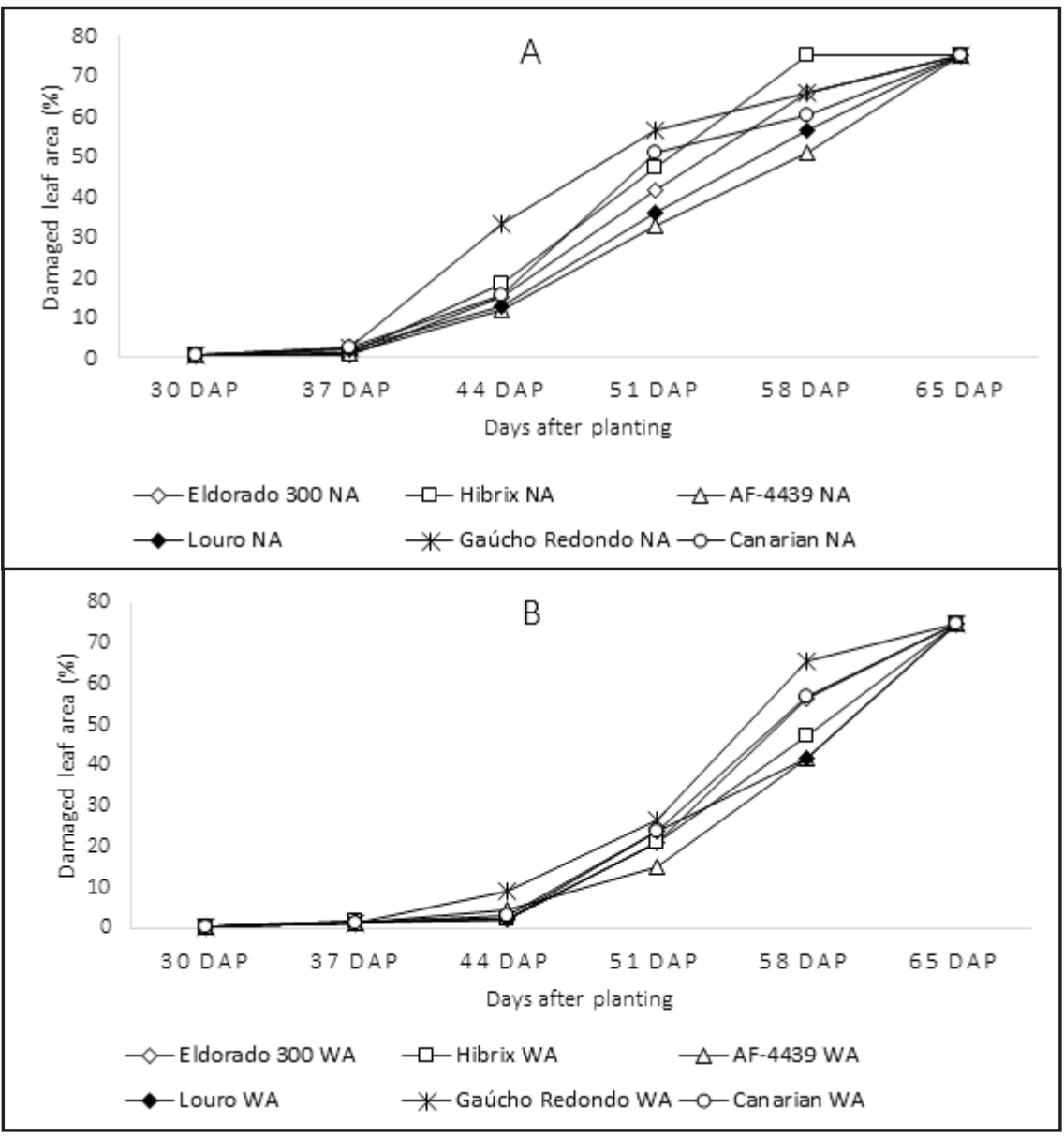

Figure 4. Temporal progress of gummy stem blight (\% damaged leaf area) in melon cultivars without application (NA) (A) and with application of fungicides (WA) (B), rainy season. Gurupi, UFT, 2015.
(2007), evaluating melon cultivars in the States of Rio Grande do Norte and Ceará, obtained average productivities between 24.5 and $32.2 \mathrm{t} / \mathrm{ha}$, results similar to the ones found in the municipality of Gurupi-TO. This fact shows that the region has potential to develop the crop when compared to the main producing poles of the country, Brazilian Northeastern States. In melon growing during the dry season, cultivars, even presenting disease on leaves, showed good productivity and quality of fruits. This can be explained due to the period of the onset disease, since the fruits were already formed and in ripening process, with no time for the disease to cause significant damage. In relation to total soluble solids (TSS), which represent the "sweetness" of the fruit, Chitarra \&Chitarra (2005) state that organic acids enhance, with sugars, perception of specific flavor in melon. Melon cultivar Gaúcho Redondo differed statistically from other treatments, with or without fungicides, not reaching a satisfactory content ( 8 and $7.1^{\circ}$ Brix, respectively). For Costa (2008), melon should have minimum level of $9^{\circ}$ Brix for commercialization. Values above $12^{\circ}$ Brix represent fruit export type pattern. In this case, the authors state that the following cultivars fit: Eldorado 300 with 12.8 and $12.5^{\circ}$ Brix, Hibrix, 12.9 and $12.7^{\circ}$ Brix and Louro, 12.5 and $12^{\circ} \mathrm{Brix}$, in the treatments with and without fungicide application, respectively. Verzera et al. (2014), evaluating total soluble solids in melon of inodorus group (yellow) cultivated in rootstocks and in a greenhouse, under controlled conditions, obtained values which ranged from 14.09 to $16.29^{\circ}$ Brix. It is possible to state that, due to cultivation conditions, the values do not present in a way different from those found in Gurupi-TO.

\section{Experiment in the rainy season}

The climatic variables recorded in the period in which the trial was carried out were total rainfall of 325 $\mathrm{mm}$. The average air temperature ranged from $19.7^{\circ} \mathrm{C}$ (minimum) to $34.3^{\circ} \mathrm{C}$ (maximum), relative humidity was above $80 \%$. Between minimum and maximum temperatures allowed leaf improvement, with frequent rain, providing favorable conditions for gummy stem blight.

All the cultivars showed similar behavior in relation to Area Under Disease Progress Curve (AUDPC) (Figure 3), where the authors did not observe significant differences among each other. Comparing treatments with and without fungicide application, the authors observed significant differences among each other, with fungicides, decreasing the values of AUDPC, in all the tested cultivars. In the rainy season, the authors verified that differently from the dry season, any cultivar differed significantly in relation to resistance, showing high values for AUDPC, confirming that the weather plays an important role in the development of the disease, reiterating Santos et al. (2011).

The temporal progress of the disease (Figure 4A) shows the evolution of the affected leaf area (ALA) by the disease 
in relation to the time, for the treatment without fungicides. Comparing severity of affected leaf area by gummy stem blight during rainy season with the one observed in the dry season without fungicide, the authors verified that the disease has begun 22 days earlier. Cultivar Gaúcho Redondo, which during the dry season showed lower severity, and because of this the cultivar endured the disease better, did not show the same behavior in an environment favorable for pathogen development, where at 51 DAP showed the highest percentage of damaged leaf area, $56.5 \%$. Hibrix was the first cultivar to reach $75 \%$ of damaged leaf area. The other cultivars also showed the same level of severity, before the end of the crop cycle, showing that, with no exception, were susceptible to the disease, under favorable climatic conditions prevailing in the rainy season.

The temporal progress of the disease (Figure 4B) shows that the evolution of the damaged leaf area in relation to time for the treatment with fungicide application, which could only slow evolution of the disease, in general, did not prevent all cultivars reaching the maximum value of ALA at 65 DAP. Severity levels verified with fungicide application were the same to the ones found in treatments without fungicides, demonstrating that these products are not able to control the disease in this time of the year (rainy season), which is far too favorable for the development of stem blight. In these conditions, the authors did not observe fruit production with minimum marketing standard, both in treatments with and without fungicides due to the fast and severe disease attack from flowering stage on. Besides the weather conditions favorable for the development of the disease at this time, the disease control is difficult, due to the survival of the pathogen in soil, cultural remains and host plants and the difficulty to obtain cultivars resistant to the disease (Santos, 2012).

The South Region of Tocantins has potential to become a leading pole of melon production, according to the results obtained in this study, with high productivities and quality of fruits. The cultivation should be carried out in the dry season of the year in order to avoid favorable conditions for the development of gummy stem blight, a disease which showed to be very aggressive under favorable conditions prevailing in the rainy season. Fungicide application can help in the productive processes since it is associated with planting during the dry season and with the use of an appropriate management of the crop.

\section{ACKNOWLEDGEMENT}

To Coordination of Improvement of higher education personnel (CAPES), for granting scholarship for the first author and to Secretary of Economic Development, Science, Technology and Innovation of the State of Tocantins (Secretaria do Desenvolvimento Econômico, Ciência, Tecnologia e Inovação do Estado do Tocantins) for financial support.

\section{REFERENCES}

AVESKAMP, MM; DEGRUYTER，J; WOUDENBERG, JHC; VERKLEYAND, GJM; CROUS, PW. 2010. Highlights of the Didymellaceae: A polyphasic approach to characterize Phoma and related pleosporalean genera. Studies in Mycology 65: 1-60.

BREWER, MT; RATH, M; LI, HX. 2015. Genetic diversity and population structure of cucurbit gummy stem blight fungi based on microsatellite markers. Phytopathology 105: 815-824.

CHITARRA, MIF; CHITARRA, AB. 2005. Póscolheita de frutos e hortaliças: fisiologia e manuseio. Lavras: UFLA. 785p.

COSTA ND. 2008. A cultura do melão. Petrolina: Embrapa. 191p

FAO. 2015. 10 de setembro. Production. Disponível em http://faostat3.fao.org/ download/Q/QC/E/

FREITAS, JG; CRISÓSTOMO, JR; SILVA, FP; PITOMBEIRA, JB; TÁVORA, JAF. 2007. Interação entre genótipo e ambiente em híbridos de melão amarelo no nordeste do Brasil. Revista Ciência Agronômica 38: 176-181.

HARGREAVES, GH; SAMANI, ZA. 1985. Reference crop evapotranspiration from temperature. Applied Engineering in Agriculture 1: 96-99.

KEINATH, AP. 2000. Effect of protectant fungicide application schedules on gummy stem blight epidemics and marketable yield of watermelon. Plant Disease 84: 254-260.

KEINATH, AP. 2001. Effect of fungicide applications scheduled to control gummy stem blight on yield and quality of watermelon fruit. Plant Disease 85: 53-58.

KEINATH, AP. 2011. From native plants in central Europe to cultivated crops worldwide: The emergence of Didymella bryoniae as a cucurbit pathogen. Hortscience 46: 532-535.

KEINATH, AP. 2014. Differential susceptibility of nine cucurbit species to the foliar blight and crown canker phases of gummy stem blight. Plant Disease 98: 247-254.

PEREIRA FILHO, JV; BEZERRA, FML; SILVA, ARA; SOUSA, CCM; CASTRO, JM. 2014. Frequência de irrigação e aplicação de N em meloeiro irrigado por gotejamento nas condições semiáridas do Nordeste. Científica 42: 11-22.

QUEIROGA, RCF; PUIATTI, M; FONTES, PCR; CECON, PR; FINGER, FL. 2007. Influência de doses de nitrogênio na produtividade e qualidade do melão Cantalupensis sob ambiente protegido. Horticultura Brasileira 25: 550-556.

SANTOS, GR; CAFÉ-FILHO, AC. 2005. Reação de genótipos de melancia ao crestamento gomoso do caule. Horticultura Brasileira 23: 945-950.

SANTOS, GR; ZAMBOLIM, L; RESENDE, JAM; COSTA, H. 2005a. Manejo integrado de doenças da melancia. Viçosa:UFV. 70p.

SANTOS, GR; CAFÉ-FILHO, AC; LEÃO, FF; CÉSAR, M; FERNANDES, LE. 2005 b. Progresso do crestamento gomoso e perdas na cultura da melancia. Horticultura Brasileira 23: $230-234$.

SANTOS, GR; CAFÉ-FILHO, AC; REIS, A. 2006. Resistência de Didymella bryoniae a fungicidas no Brasil. Fitopatologia Brasileira 31: 476-482.

SANTOS, GR; LEÃO, EU; CASTRO, HG; NASCIMENTO, IR; SARMENTO, RA; SARMENTO-BRUM, RBC. 2011. Crestamento gomoso do caule de melancia: Etiologia, epidemiologia e medidas de controle. Journal of Biotecnology and Biodiversity 2: 52-58.

SANTOS, GR. 2012. In: Produção integrada de fruteiras tropicais. Produção integrada de melancia. Cruz das Almas: Embrapa. p.319-370.

SANTOS, HG; ALMEIDA, J; OLIVEIRA, JD; LUMBRERAS, J; ANJOS, LD; COELHO, M; JACOMINE, P; CUNHA, TD; OLIVEIRA, VD. 2013. Sistema brasileiro de classificação de solos. Rio de Janeiro: Embrapa. 353p.

SHANER, G; FINNEY, RE. 1977. The effect of nitrogen fertilization on the expression of slow-mildewing resistance in Knox Wheat. Phytopathology 67: 1051-1056.

SILVA, AG; BARROS, AS; SILVA, LHCP; MORAES, EB; PIRES, R; TEIXEIRA, 
IR. 2009. Avaliação de cultivares de sorgo granífero na safrinha no sudoeste do estado de Goiás. Pesquisa Agropecuária Tropical 39: 168-174.

SOUSA, SCR; SANTOS, GR; RODRIGUES, AC; BONIFÁCIO, A; DALCIN, MS; JULIATTI, FC. 2014. Escala diagramática para avaliação da severidade do crestamento gomoso do caule em melancia. Bioscience Journal 30: 1314-1324.
REIS, C; CASTRO, NMR; PEDROLLO, O; LOUZADA, JA. 2013. Resposta da cultura de melão a diferentes intensidades e frequências de irrigação em Porto Nacional-TO. Revista Brasileira de Recursos Hídricos 18: 195-204.

VARGAS, PF; CASTOLDI, R; CHARLO, HCO; BRAZ, LT. 2008. Qualidade de melão rendilhado (Cucumis melo L.) em função do sistema de cultivo. Ciência e Agrotecnologia 32: $137-142$.
VERZERA, A; DIMA, G; TRIPODI, G; CONDURSO, C; CRINÒ, P; ROMANO, D; MAZZAGLIA, A; LANZA, CM; RESTUCCIA, C; PARATORE, A. 2014. Aroma and sensory quality of honeydew melon fruits (Cucumis melo L. Subsp. melo var. Inodorus H. Jacq.) in relation to different rootstocks. Scientia Horticulturae 169: 118124. 